\title{
Collaborative Group Activities in The Context of Learning Styles on Web 2.0 Environments: An Experimental Study
}

\author{
Ayşegül Pürbudak* \\ Distance Education Research Center, Aksaray University, Aksaray, Turkey \\ ORCID: 0000-0001-7064-0263 \\ Ertuğrul Usta \\ CEIT Department, Necmettin Erbakan University, Konya, Turkey
} ORCID: 0000-0001-6112-9965

Article history

\section{Received:}

06.10 .2020

Received in revised form: 23.12.2020

Accepted:

24.12.2020

Key words:

Online collaborative learning,

Web 2.0 environments,

Learning styles
The aim of this research is to determine the learning styles of Web 2.0 based collaborative group activities; to examine the effects on academic achievement, online cooperative learning attitude level, computer thinking skill level. The research was carried out with a quantitative method and a pretest-posttest control group quasi-experimental design was used. Data were collected through Computational Thinking Skill Level scale, Online Cooperative Learning Attitude Scale and academic achievement test. The research was conducted for 10 weeks in the 20192020 academic year, within the scope of Information Technologies and Software course, with 83 6th grade students. The experimental group consists of 43 students and the control group consists of 40 students. In the research, one of the learning style theories, Kolb Learning Style model was used. In the experimental group, Web 2.0 based activities developed by the researcher were applied and the experimental group students produced content with Web 2.0 tools. In the control group, the lesson was taught in the way the current program suggested in schools. As a result, a meaningful difference was determined between students' academic achievement scores, online cooperative attitude levels, computer thinking levels and learning styles. According to these variables, the students with the discriminating learning style show the highest success. In addition, as a result of the research, it was determined that there are some features and developments other than the learning style feature in students. Learning environments other than the learning path of the learning style can be provided. Similar studies can be conducted by using the learning style inventory based on different theories.

\section{Introduction}

Individuals differ in their choice of access to information, their processing of information, the sources of information they want to use, and their learning styles. This

\footnotetext{
" Correspondency: aysegulpurbudak2@gmail.com
} 
situation causes a difference in learning needs while using the same environment in the learning process (Riding \& Rayner, 1998a). With the development of technology, different learning environments where individual differences are taken into account have emerged. Distance learning, which is one of these learning environments is defined as information technology applications that brings teachers and students in different environments together with various educational activities (Schlosser \& Simonson, 2006). The purpose of these activities in distance education is to provide a learning environment that constitutes the emergence of direct information and the reflection of this information on the performance. Learning in distance education is carried out individually or collaboratively (Netteland, 2003).

Online learning, which is a sub-dimension of distance education, emphasizes collaborative participation rather than individual student participation (Ergül, 2006). Because it is known that one of the factors that increase the efficiency of education in online learning environment is interaction. One of the common points of most studies in distance education is that there should be interaction (Phipps, 2015). Creating knowledge in the online learning environment can occur through collaborative activities (Zhu, 2012). Online collaborative learningcontributes to the participants' sharing knowledge, gaining different perspectives, and creating a common understanding in the knowledge they obtained by providing group interaction (Stacey, 2007).

Open educational resources, a concept related to online learningis an existing organization that emphasizes sharing information and is approved by many institutions and organizations, primarily in well-known universities. Open educational resources are in fact a form of online learning environment. With the emergence of Web 2.0 technologies, there has been an increase in the information and speed produced. In this respect, Web 2.0 technologies have provided an infrastructure to create open access sources (Durdu \& Durdu, 2016). Web 2.0 technologies offer a renewal from being an internet reader to being an internet literate. In other words, the internet has turned into a platform where content is produced, shared, combined and transferred with the participants, rather than being the medium where readymade information is consumed (Horzum, 2010).

Online learning environments provide many opportunities for learning to take place regardless of time and place (Gudawardena \& McIsaac, 2003). That said, online learning environments have some deficiencies. One of them is that students are not well aware of their personal differences. Having different personality traits, having different learning styles, processing information in different ways cause differentiation in learning needs while using the same learning environment (Riding \& Rayner, 1998b). Another element to be considered in the online learning environment is learning styles that reflect students' choices for different learning and teaching activities and cognitive styles related to how students process information (Özyurt \& Özyurt, 2015). Students' learning experiences are enriched if teaching materials are created by considering their learning styles (Brickell, 1993). In addition, it was emphasized that positive feedback was obtained from students in adapting learning strategies according to students' cognitive styles (Triantafillou, Pomportsis, \& Demetriadis, 2003). In this study, because interaction is an important factor in distance education, the online collaborative learning environment, Web 2.0-based activities that enable students to be production-oriented rather than consumption-oriented in online activities, and learning styles in online learning, were taken into account in the creation of online collaborative groups and an application has been implemented. 


\section{The Aim of the Study}

In the research, in the context of learning styles of Web 2.0 based group activities it is aimed to examine the effect on academic achievement, online cooperative learning attitude level, computer thinking skill level. For this purpose, answers were sought for the subproblems given below:

(1) Does the experimental application contribute to the academic achievement scores of the students according to their learning styles?

(2) Does the experimental application contribute to the attitude scores towards online collaborative learning according to the learning styles of the students?

(3) Does the experimental application contribute to the computational thinking skill scores according to the learning styles of the students?

\section{Significance of the Study}

A review of the literature reveals that online collaborative learning has many positive effects, and thus it is used in many areas, also Web 2.0 tools have a positive effect on learning and that learning can be more effective by taking into account learning styles (Driscoll, 2002; Hargadon, 2009; Tuan, Chin, \& Cheng, 2005; Pürbudak \& Usta, 2019). In the literature, there are no studies that include online collaborative learning, Web 2.0 tools and learning styles. This study, which brings together these three important concepts that are important in many ways, has the potential to contribute to the literature. While creating collaborative groups, the heterogeneous structure of the groups is frequently emphasized in the literature. However, in this research, online collaborative groups which are heterogeneous in terms of success, online cooperative learning attitude and computer learning level, and homogeneous in terms of learning styles were resorted to. In the face-to-face interviews with the students, they stated that they do not want to take part in group work that are heterogeneous in terms of learning style. In this sense, it is another dimension that makes the research different and is expected to contribute to the literature.

\section{Methodology}

This research was carried out with "Pre Test - Post Test Control Group Semi Experimental Design" which is one of the semi-experimental design types. First, two groups are formed from the existing groups, objectively. Groups are assigned randomly, one as experimental and the other as control group. Then, the measurement is taken with the independent variables in the two groups that are assigned. While the experimental process is applied to the experimental group, it is not applied to the control group. After the implementation process, the same independent variables are measured again from both groups (Büyüköztürk, Çakmak, Akgün, Karadeniz, \& Demirel, 2018).

\section{Study Group}

The study group of the research consists of 83 6th grade students studying in a state school in the 2019-2020 academic year. Since the experimental process of the research will be conducted with online collaborative groups formed according to learning styles, the "Kolb Learning Style Inventory III" scale was applied primarily to determine the learning styles of the experimental and control group students. 
Table 1. Learning style distribution of the study group students

\begin{tabular}{lll}
\hline \multirow{2}{*}{ Learning Styles } & Groups & \\
\cline { 2 - 3 } & Experimental & Control \\
\hline Accomm odating & 10 & 6 \\
Diverging & 14 & 10 \\
Converging & 8 & 9 \\
Assimilating & 11 & 15 \\
Total & 43 & 40 \\
\hline
\end{tabular}

When Table 1 is examined, the experimental group consists of 43 students with 10 accommodating, 14 diverging, 8 converging and 11 assimilating learning styles. The control group, on the other hand, consists of 40 students with 6 accommodating, 10 diverging, 9 converging, and 15 assimilating learning styles.

\section{The Application Process}

The research was conducted within the scope of Information Technologies and Software course, which is a compulsory course in secondary schools. Before the application, lesson plans were prepared by the researcher, taking the expert opinion. Table 2 below shows the activities to be carried out during the research process and the weekly processes planned by these activities.

Table 2 Weekly activities regarding the implementation process

\begin{tabular}{|c|c|}
\hline Week & Activities Performed by Weeks \\
\hline 1 & $\begin{array}{l}\text { - Development of materials prepared with Web } 2.0 \text { tools to be used by the researcher in the } \\
\text { experimental group. }\end{array}$ \\
\hline 2 & $\begin{array}{l}\text { - Application of the "Kolb's Learning Styles" scale to the experimental and control group students. } \\
\text { - Application of academic achievement test as a pre-test to experimental and control group students. } \\
\text { - Application of the "Computer Thinking Skill Levels" scale to the experimental and control group } \\
\text { students as a pre-test. } \\
\text { - Application of the "Attitude to Online Cooperative Learning" scale as a pre-test for experimental } \\
\text { and control group students. }\end{array}$ \\
\hline 3 & $\begin{array}{l}\text { - Separation of experimental group students into online collaborative groups according to their } \\
\text { learning styles. } \\
\text { - } \quad \text { Introduction of whiteboard.com, which is an online learning environment. } \\
\text { - } \quad \text { Registration of experimental group students to beyazpano.com. }\end{array}$ \\
\hline 4 & - $\quad$ Conducting a pilot study \\
\hline 5-6 & $\begin{array}{l}\text { - Prepared for beyazpano.com in LearningApps, a Web } 2.0 \text { tool to prepare an application on the } \\
\text { learning management system "Virus types and malware", "Information sharing tools"; pairing, } \\
\text { horse racing, who wants to be a millionaire? giving the applications as activities. } \\
\text { Explaining "Virus types and malware", "Information sharing tools" to the control group students } \\
\text { within the scope of the current education program. }\end{array}$ \\
\hline 7-8-9 & $\begin{array}{l}\text { - Introducing the Pixton cartoon-made Web } 2.0 \text { tool to the experimental group students and } \\
\text { recording them. } \\
\text { - Caricature making activities on "Information Data Security" using Pixton Web } 2.0 \text { tool on } \\
\text { beyazpano.com. } \\
\text { - Explanation of account opening and channel creation on YouTube video sharing site. } \\
\text { - Receiving recordings of introducing Powtoon digital story making Web } 2.0 \text { tool. } \\
\text { Delivery of digital story making activities on "Virtual Bullying" using Powtoon Web } 2.0 \text { tool on } \\
\text { beyazpano.com. } \\
\text { Explaining "Information Data Security" and "Virtual Bullying" to the control group students } \\
\text { within the current curriculum }\end{array}$ \\
\hline 10 & $\begin{array}{l}\text { - Application of the academic achievement test as a post test to the experimental and control group } \\
\text { students } \\
\text { - Application of the "Computer Thinking Skill Levels" scale to the experimental and control group } \\
\text { students as a post-test } \\
\text { - Application of the "Online Cooperative Learning Attitude" scale to the experimental and control } \\
\text { group students as a post-test }\end{array}$ \\
\hline
\end{tabular}


In the study, "Kolb's Learning Styles", "Computer Thinking Skill Levels", "Online Cooperative Learning Attitude" scales and academic achievement test were applied to the experimental and control group as a pre-test. Within the scope of Web 2.0 based collaborative group activities to the experimental group students; according to the ADDIE instructional design model, Web 2.0 based activities developed by the researcher were applied and the experimental group students produced content with Web 2.0 tools. In the control group, lessons were conducted within the scope of the current curriculum. The research process took 10 weeks in total. At the end of this period, "Kolb's Learning Styles", "Computational Thinking Skill Levels", "Online Collaborative Learning Attitude" scales and academic achievement test were applied to both groups as a post-test.

\section{Data Collection Tools}

\section{Kolb's Learning Styles III Scale}

Kolb's Learning Styles III scale, adapted by Gencel (2007), was used to determine students' learning styles. Cronbach-alpha reliability coefficient values of the scale were as follows for these; Concrete Experience 0.76, Reflective Observation 0.71, Abstract Conceptualization 0.80, Active Experience 0.75, Abstract Conceptualization-Concrete Experience 0.84, Active Experience-Reflective Observation 0.79. The scale consists of 12 questions and 48 sub-items. The four options in each item are scored between 1 and 4 . The lowest score obtained from the scale is 12 and the highest score is 48 .

\section{Academic Achievement Test}

The Academic Achievement Test, Information Technologies and Software course, was prepared by taking into consideration the unit gains determined within the scope of the "Ethics and Safety" unit in the 6th grade curriculum. The test, which is applied as a pre-post test, consists of 25 multiple choice questions. The questions were formed from the question pool prepared by taking into account the gains of the unit of "Ethics and Safety", using the opinion of three teachers and an expert, and applied as a central examination.

\section{Computational Thinking Skill Levels}

The Computational Thinking Skill Levels scale developed by Korkmaz, Çakır, \& Özden, (2015) was developed to describe the computer thinking skill levels of students. The scale consists of 5 factors and 22 items: creativity, problem solving, algorithmic thinking, collaboration and critical thinking. Items are from negative to positive; it is scaled to never (1), rarely (2), sometimes (3), usually (4), always (5). Cronbach's alpha ( $\alpha$ ) values were calculated for each factor in the scale consisting of 5 factors, and confirmatory factor analyzes were performed (Korkmaz et al., 2015). Cronbach-alpha reliability coefficient values of the scale; creativity 0.64 , algorithmic thinking 0.762 , collaboration 0.811 , critical thinking 0.714 , problem solving 0.867 .

\section{Online Cooperative Learning Attitude Scale}

"Online Cooperative Learning Attitude Scale" developed by Korkmaz (2012) was used to measure the attitudes of students who were divided into collaborative groups according to their learning styles towards online collaborative learning. Online Cooperative Learning Attitude Scale is a five-point Likert-type scale. It consists of two factors and 17 
items. Cronbach's Alpha values of the factors are .899 and .822 . In this context, it can be said that both factors and the general scale can make consistent measurements (Korkmaz, 2012).

\section{Data Analysis}

The quantitative data obtained by data collection tools were analyzed using SPSS (Statistical Package for Social Sciences) for Windows 21.00 software. In case of excessive deviation of score distributions from normal $(\mathrm{p}<.05)$, tests that provide normality assumption should not be used (Büyüköztürk, 2018). The $\mathrm{p}>.05$ value of Kolmogorov-Smirnov Test results in the analysis of the data of academic achievement test, Online Cooperative Learning Attitude Scale, and Computational Thinking Skill Levels Scale was not provided. In addition, nonparametric tests were used because the mean and median values were not close to each other and the skewness and kurtosis values were not between -1.5 and +1.5 . Kruskal-Wallis Variance Analysis was conducted to examine whether the posttest scores of the experimental group students showed a statistically significant difference according to their learning styles. Mann Whitney U test was applied to determine which groups had a significant difference. In the analysis, 0.05 significance level was taken into account.

\section{Findings}

\section{Does the experimental application contribute to the academic success level of the students according to their learning styles?}

Findigs pertinent to the sub-questioin:"Does the experimental application contribute to the academic success level of the students according to their learning styles?" are presented in Table 3.

Table 3 Findings regarding the contribution of the experimental application to the academic achievement of the students according to their learning styles

\begin{tabular}{lllllll}
\hline Learning Style & $\mathbf{N}$ & Average Rank & Sd & $\mathbf{x}^{\mathbf{2}}$ & $\mathbf{P}$ & Meaningful difference \\
\hline Accommodating & 10 & 18,50 & 3 & \multirow{2}{*}{22,34} & .000 & $\begin{array}{l}\text { Assimilating-Accommodating } \\
\text { Converging-Accommodating } \\
\text { Diverging }\end{array}$ \\
Converging & 8 & 11,68 & 33,25 & & Assimilating-Diverging \\
Assimilating & 11 & 30,14 & & & Converging-Diverging \\
\hline
\end{tabular}

When Table 3 is examined, it is seen that there is a meaningful difference in the posttest academic achievement scores of the experimental group students according to their learning styles $(\mathrm{x} 2=22.34 ; \mathrm{p}<.05)$. Considering the group rank average, academic achievement scores from the highest to the lowest; are in the form of converging, assimilating, accommadating, diverging. As a result of the statistical analysis, a meaningful difference was found between those with converging learning style and those who with accommodating and diverging learning style, and those with assimilating learning style and those with diverging and accommodating learning style. This difference is in the direction of those who are with converging and assimilating learning style. 


\section{Does the experimental application contribute to the online cooperative learning attitude level according to the learning styles of the students?}

Findings related to the question: "Does the experimental application contribute to the online cooperative learning attitude level according to the learning styles of the students?" are presented in Table 4.

Table 4 Findings regarding online cooperative learning attitudes of the experimental application according to students learning styles

\begin{tabular}{|c|c|c|c|c|c|c|}
\hline Learning Style & $\mathbf{N}$ & Average Rank & Sd & $\mathbf{x}^{2}$ & $\mathbf{P}$ & Meaningful difference \\
\hline Accommodating & 10 & 19,05 & \multirow{4}{*}{3} & \multirow{4}{*}{10.373} & \multirow{4}{*}{.016} & \multirow{4}{*}{$\begin{array}{l}\text { Converging-Accommodating } \\
\text { Assimilating-Diverging } \\
\text { Converging-Diverging }\end{array}$} \\
\hline Diverging & 14 & 15,21 & & & & \\
\hline Converging & 8 & 30,94 & & & & \\
\hline Assimilating & 11 & 26,82 & & & & \\
\hline
\end{tabular}

When Table 4 is examined, it is seen that there is a meaningful difference in the posttest online cooperative learning attitudes scores of the experimental group students according to their learning styles $\left(x^{2}=10.373 ; \mathrm{p}<.05\right)$. Considering the group rank average, online cooperative learning attitudes scores from the highest to the lowest; are in the form of converging, assimilating, accommodating, diverging. As a result of the statistical analysis, a meaningful difference was found between those with converging learning style and those with accommodating and diverging learning style, and those with assimilating learning style and those with diverging learning style. This difference is in the direction of those with converging and assimilating learning style.

\section{Does the experimental application contribute to the computational thinking skill levels according to the learning styles of the students?}

Findings for the following question: "Does the experimental application contribute to the computer thinking skill levels according to the learning styles of the students?" are presented in Table 5.

Table 5 Findings regarding computational thinking skill scores of the experimental application according to students learning styles

\begin{tabular}{lllllll}
\hline Learning Style & $\mathbf{N}$ & Average Rank & Sd & $\mathbf{x}^{\mathbf{2}}$ & $\mathbf{P}$ & Meaningful difference \\
\hline Accommodating & 10 & 16,50 & 3 & \multirow{2}{*}{14,53} & .002 & $\begin{array}{l}\text { Assimilating-Accommodating } \\
\text { Converging-Accommodating } \\
\text { Diverging }\end{array}$ \\
Converging & 14 & 14,86 & 30,44 & & Assimilating-Diverging \\
Assimilating & 11 & 29,95 & & & Converging-Diverging \\
\hline
\end{tabular}

When Table 5 is examined, it is seen that there is a meaningful difference in the posttest computational thinking skill scores of the experimental group students according to their learning styles $\left(x^{2}=14,53 ; p<.05\right)$. Considering the group rank average, computational thinking skill scores from the highest to the lowest; are in the form of converging, assimilating, accommodating, diverging. As a result of the statistical analysis, a meaningful difference was found between those with converging learning style and those with accommodating and diverging learning style, and those with assimilating learning style and those with diverging and accommodating the learning style. This difference is in the direction of those with converging and assimilating learning style. 
Does the experimental application contribute to the creativity level of the sub-dimension of computational thinking skills according to students learning styles?

Findings of the sub-problem: "Does the experimental application contribute to the creativity level of the sub-dimension of computational thinking skills according to students learning styles?" are presented in Table 6.

Table 6 Findings regarding the contribution of the experimental application to the creativity levels of the students according to their learning styles

\begin{tabular}{lllllll}
\hline Learning Style & N & Average Rank & Sd & $\mathbf{x}^{2}$ & $\mathbf{P}$ & Meaningful difference \\
\hline Accommodating & 10 & 20.85 & 3 & 8.60 & .035 & Diverging- Converging \\
Diverging & 14 & 27.75 & & & & \\
Converging & 8 & 13.06 & & & & \\
Assimilating & 11 & 22.23 & & & & \\
\hline
\end{tabular}

When Table 6 is examined, it is seen that there is a meaningful difference in the posttest creativity level of the sub-dimension of computational thinking skills of the experimental group students according to their learning styles $\left(x^{2}=8.60 ; p<.05\right)$. Considering the group rank average, creativity level of the sub-dimension of computational thinking skills from the highest to the lowest arein the form of diverging, assimilating, accommodating, converging. As a result of the statistical analysis, a meaningful difference was found between those with diverging learning style and those with converging learning style. This difference is in the direction of those with diverging learning style.

Does the experimental application contribute to the algorithmic thinking level of the sub-dimension of computer thinking skills according to students learning styles?

Findings pertaining to "Does the experimental application contribute to the algorithmic thinking level of the sub-dimension of computer thinking skills according to students' learning styles?" question are presented in Table 7.

Table 7 Findings regarding the contribution of the experimental application to the algorithmic thinking levels of the students according to their learning styles

\begin{tabular}{|c|c|c|c|c|c|c|}
\hline Learning Style & $\mathbf{N}$ & Average Rank & Sd & $\mathbf{x}^{2}$ & $\mathbf{P}$ & Meaningful difference \\
\hline Accommodating & 10 & 11.40 & \multirow{4}{*}{3} & \multirow{4}{*}{24.63} & \multirow{4}{*}{.000} & \multirow{4}{*}{$\begin{array}{l}\text { Assimilating-Accommodating } \\
\text { Converging-Accommodating } \\
\text { Converging-Assimilating } \\
\text { Converging-Diverging }\end{array}$} \\
\hline Diverging & 14 & 16.11 & & & & \\
\hline Converging & 8 & 36.00 & & & & \\
\hline Assimilating & 11 & 28.95 & & & & \\
\hline
\end{tabular}

When Table 7 is examined, it is seen that there is a meaningful difference in the posttest algorithmic thinking level of the sub-dimension of computational thinking skills of the experimental group students according to their learning styles $\left(x^{2}=24.63 ; p<.05\right)$. Considering the group rank average, algorithmic thinking level of the sub-dimension of computational thinking skills from the highest to the lowest in the form of converging, assimilating, diverging, accommodating. As a result of the statistical analysis, a meaningful difference was found between those with converging learning style and those with accommodating, assimilating and diverging learning style, and those with assimilating learning style and those with accommodating learning style. This difference is in the direction of those with converging and assimilating learning style. 
Does the experimental application contribute to the level of collaboration of the subdimension of computational thinking skills according to students learning styles?

Findings belonging to the sub-problem: "Does the experimental application contribute to the level of collaboration of the sub-dimension of computational thinking skills according to students learning styles?" are presented in Table 8.

Table 8 Findings regarding the contribution of the experimental application to the cooperation levels according to students learning styles

\begin{tabular}{lllllll}
\hline Learning Style & $\mathbf{N}$ & Average Rank & Sd & $\mathbf{x}^{\mathbf{2}}$ & $\mathbf{P}$ & Meaningful difference \\
\hline Accommodating & 10 & 16.10 & 3 & \multirow{2}{*}{10.33} & .016 & Converging-Accommodating \\
Diverging & 14 & 18.46 & & & & \\
Converging & 8 & 31.50 & & & & \\
Assimilating & 11 & 24.95 & & & & \\
\hline
\end{tabular}

When Table 8 is examined, it is seen that there is a meaningful difference in the posttest cooperation level of the sub-dimension of computational thinking skills of the experimental group students according to their learning styles $\left(x^{2}=10.33 ; \mathrm{p}<.05\right)$. Considering the group rank average, cooperation level of the sub-dimension of computational thinking skills from the highest to the lowest in the form of converging, assimilating, diverging, accommodating. As a result of the statistical analysis, a meaningful difference was found between those with converging learning style and those with accommodating and assimilating learning style. This difference is in the direction of those with converging learning style.

Does the experimental application contribute to the level of critical thinking in the subdimension of computational thinking skills according to students learning styles?

Findings linked to the question: "Does the experimental application contribute to the level of critical thinking in the sub-dimension of computational thinking skills according to students learning styles?" are presented in Table 9.

Table 9 Findings regarding the contribution of the experimental application to the critical thinking levels of the students according to their learning styles

\begin{tabular}{lllllll}
\hline Learning Style & $\mathbf{N}$ & Average Rank & Sd & $\mathbf{x}^{\mathbf{2}}$ & $\mathbf{P}$ & Meaningful difference \\
\hline Accommodating & 10 & 22.85 & 3 & 10.72 & .013 & Converging- Assimilating \\
Diverging & 14 & 19.25 & & & & \\
Converging & 8 & 13.19 & & & & \\
Assimilating & 11 & 31.14 & & & & \\
\hline
\end{tabular}

When Table 9 is examined, it is seen that there is a meaningful difference in the posttest critical thinking level of the sub-dimension of computational thinking skills of the experimental group students according to their learning styles $\left(x^{2}=10.72 ; p<.05\right)$. Considering the group rank average, critical thinking level of the sub-dimension of computational thinking skills from the highest to the lowest in the form of assimilating, accommodating, diverging, converging. As a result of the statistical analysis, a meaningful difference was found between those with converging learning style and those with assimilating learning style. This difference is in the direction of those with converging learning style. 
Does the experimental practice contribute to the level of problem solving in the subdimension of computational thinking skills according to students learning styles?

Findings connected to the sub-problem: "Does the experimental practice contribute to the level of problem solving in the sub-dimension of computer thinking skills according to students' learning styles?" are presented in Table 10.

Table 10 Findings regarding the contribution of the experimental practice to the level of problem solving according to students learning styles

\begin{tabular}{lllllll}
\hline Learning Style & $\mathbf{N}$ & Average Rank & Sd & $\mathbf{x}^{\mathbf{2}}$ & $\mathbf{P}$ & Meaningful difference \\
\hline Accommodating & 10 & 18.90 & 3 & 10.63 & .014 & Converging-Accommodating \\
Diverging & 14 & 16.86 & & & & $\begin{array}{l}\text { Converging-Assimilating } \\
\text { Converging-Diverging }\end{array}$ \\
Assimilating & 11 & 22.73 & & & & \\
\hline
\end{tabular}

When Table 10 is examined, it is seen that there is a meaningful difference in the posttest problem solving level of the sub-dimension of computational thinking skills of the experimental group students according to their learning styles $\left(\mathrm{x}^{2}=10.63 ; \mathrm{p}<.05\right)$. Considering the group rank average, problem solving level of the sub-dimension of computational thinking skills from the highest to the lowestis in the form of converging, assimilating, accommodating, diverging. As a result of the statistical analysis, a meaningful difference was found between those with converging learning style and those with accommodating, assimilating and diverging learning style. This difference is in the direction of those with converging learning style.

\section{Conclusion and Discussion}

In the research, in the context of learning styles of Web 2.0 based collaborative group activities, its effects on academic achievement, online cooperative learning attitude level and computational thinking skill level were examined. As a result of the application, a meaningful difference was determined between students' academic achievement scores, online collaborative attitude levels, computer thinking levels and learning styles. It was determined that students with converging learning style have higher level academic achievement, online cooperative attitude level, computational thinking than students with accommodating and diverging learning styles. For students with assimilating learning style it was determined that academic achievement, online cooperative attitude level, computational thinking level is higher than students with the learning styles that are accommodating and diverging. Academic achievement, online collaborative attitude level and computational thinking level from highest to lowest after application are in the form of converging, assimilating, accommodating and diverging.

Practicing thoughts, organizing information from the whole to the piece are the striking aspects of individuals with a learning style that is converging (Uygungül, 2016). Therefore, the success of students with a discriminating learning style in practical studies coincides with Kolb's learning styles model. However, it is one of the different results of the study that students with assimilating learning style show success in the first place as a result of the application. Because for students with assimilating learning style it can be said that they are not talented in subjects such as practicing, dreaming, determining the problem, and planning (Numanoğlu \& Şen, 2007). In addition, it can be stated that students with an assimilating learning style learn by listening and watching and see the teacher as an important source of 
information (Kolb, 1999). In this practice, it is thought that feedback by the teacher is effective in the success of the students with assimilating learning style. In addition, it is thought that informative videos about the use of Web 2.0 tools may also have an effect. Another differentiating result of the research belong to students with learning style that is accommodating. Individuals with this learning style realize the learning process directly through life. These individuals are open to new experiences. It is also among the preferences of establishing, implementing and executing plans. Therefore, they are expected to show success in practical exercises (Aşkar \& Akkoyunlu, 1993). However, it has shown success in the back ranks compared to other learning styles. The reason for this may be that online collaborative groups are formed homogeneously according to their learning styles. Students with a diverging learning style realize learning by feeling and watching individuals (Veznedaroğlu \& Özgür, 2005). Therefore, being a good observer may have an effect on the success of students with this learning style. In addition, it can be said that using the cooperative learning method may have an effect. The fact that it succeeds in the lowest ranks compared to other learning styles supports the characteristics of not transferring ideas to behavior (A $\breve{g c a}, 2006)$.

As a result of the implementation of Web 2.0 based activities carried out with online collaborative groups formed according to learning styles some common results were found in terms of academic achievement, online cooperative attitude level and computational thinking level. However, results differ in computer thinking sub-skills. In the creativity skill subdimension it was determined that the level of creativity of students with a diverging learning style was higher than students with a converging learning style. The fact that the diverging learning style likes techniques such as brainstorming in which different ideas are produced supports this result of the study (Ekici, 2003). The algorithmic thinking level of the students with the converging learning style was found to be higher than the students with the learning style that are assimilating, accommodating and diverging. It has been found that students with assimilating learning style are at a higher level than students with a learning style with accommodating algorithmic thinking levels. In the creativity skill sub-dimension it was determined that the level of critical thinking of students with a converging learning style was higher than students with an assimilating learning style. It is thought that the activities implemented may have improved the students' ability to look from different perspectives with converging learning style. Also, the problem solving level of the students with the converging learning style was found to be higher than the students with the learning style that assimilating, accommodating and diverging.

As a result of the application a meaningful difference was determined between students' academic achievement scores, online cooperative attitude levels, computational thinking levels and learning styles. It can be stated that converging learning style stands out in these meaningful differences. Wang, et al. (2006), in his research, found that students who have a converging learning style have the highest level of success. In addition, as a result of the research, it was determined that there are some features and developments other than the learning style feature in students. Therefore, learning styles are not unchanging characteristics (Uğur, Akkoyunlu, \& Kurbanoğlu, 2011). In this direction, learning environments other than learning style can be focused on from time to time. Different teaching management systems such as Moodle and Edmodo can be used in the delivery of the activities. The effect of the research on different levels and lessons can be examined. Similar studies can be conducted by using the learning style inventory based on different theories. 


\section{Acknowledgments}

This study is based on part of the master's thesis project written by Ayşegül Pürbudak under the supervision of Ertuğrul Usta.

\section{References}

Ăgca, R. K. (2006). Hipermedya ortamlarda öğrenme stillerine dayalı farkl gezinti yapılarının öğrenci başarısına etkisi [The effects of different navigation structures based upon learning styles on the success of the student in hypermedia environments]. Gazi University Institute of Educational Sciences. Department of Computer and Instructional Technologies. Master's thesis. Ankara.

Aşkar, P., \& Akkoyunlu, B. (1993). Kolb öğrenme stili envanteri [Kolb learning style inventory]. Education and Science, 87 (17), 37-47.

Brickell, G. (1993). Navigation and learning style. Australlian Journal Of Educational Technology, 9(2), 103-114.

Büyüköztürk, Ş. (2018). Sosyal bilimler için veri analizi el kitabı [Manual of data analysis for social sciences]. Ankara: Pegem Academy.

Büyüköztürk, Ş., Çakmak, E. K., Akgün, Ö. E., Karadeniz, Ş., \& Demirel, F. (2018). Eğitimde bilimsel araştırma yöntemleri [Scientific research methods in education]. (25th ed.). Ankara: Pegem Academy.

Durdu, L., \& Durdu, P. O. (2016). Çevrimiçi öğrenme ortamları [Online learning environments]. In K. Çağıltay \& Y. Göktaş (Eds.), Öğretim teknolojiilerinin temelleri [Instructional technology basics]. (2nd ed., Pp. 523-525). Ankara: Pegem Academy.

Driscoll, M. (2002). Web-based training: Creating e-Learning experiences (2nd ed.). San Francisco: CA: Jossey-Bass/Pfeiffer.

Ekici, G. (2003). Öğrenme stiline dayalı ögrretim ve Biyoloji dersi ögretimine yönelik ders planı örnekleri [Lesson plan examples for teaching based on learning style and Biology course]. Ankara: Gazi Publishing House.

Ergül, H. (2006). Çevrimiçi eğitimde akademik başarıyı etkileyen güdülenme yapıları [Motivation structures affecting academic achievement in online education]. The Turkish Online Journal of Educational Technology, 5 (1), 13.124-128.

Gencel, İ. E. (2007). Kolb’un deneyimsel ögrrenme kuramina dayalı ögrrenme stilleri envanteri-III'ü Türkçeye uyarlama çalışması [The study of adapting Kolb's learning styles inventory-III based on experiential learning theory into Turkish]. Dokuz Eylül University Institute of Social Sciences Journal, 9 (2), 120-139.

Gudawardena, C. N., \& McIsaac, M. S. (2003). Distance education. In D. H. Jonassen (Ed.), Handbook of reseach on educational communications and technology (2nd Editio). Mahwah, NJ: Lawrence Erlbaum Associates, Inc.

Hargadon, S. (2009). White Paper on educational networking: The important role Web 2.0 will play in education. Retrieved from http://www.elluminate.com

Horzum, M. B. (2010). Öğretmenlerin Web 2.0 araçlarından haberdarlığ ve amaçlarının çeşitli değişkenler açısından incelenmesi [Investigating teachers' Web 2.0 tools awareness, frequency and purposes of usage in terms of different variables]. International Journal of Human Sciences, 7 (1), 603-634.

Kolb, D. A. (1999). Learning style inventory: Version 3. Boston, MA: Hay/McBer Training Resources Group.

Korkmaz, Ö. (2012). A validity and reliability study of the online cooperative learning attitude scale (OCLAS). Computer \& Education, 59(4), 162-1169. https://doi.org/Doi: 10.1016/j.compedu.2012.05.021 
Korkmaz, Ö., Çakır, R., \& Özden, M. Y. (2015). Bilgisayarca düşünme beceri düzeyleri ölçeğinin (BDBD) ortaokul düzeyine uyarlanması [Investigating teachers' Web 2.0 tools awareness, frequency and purposes of usage in terms of different variables]. Gazi Journal of Educational Sciences, 1 (2), 67-86.

Netteland, G. (2003). Improved quality in large-scale implementations of e-learning in the workplace - in search of critical success factors. The Quality Dialogue: Integrating Quality Cultures in Flexible, Distance and e-Learning. (s. 108-113). Rhodes, Greece: European Distance Education Network.

Numanoğlu, G., \& Şen, B. (2007). Bilgisayar ve öğretim teknolojileri eğitimi bölümü öğrencilerinin öğrenme stilleri [Learning styles of computer education and instructional technology students]. Ahi Evran University Journal of Kırşehir Education Faculty, 8 (2).

Özyurt, Ö., \& Özyurt, H. (2015). Learning style based individualized adaptive e-learning environments: Content analysis of the articles published from 2005 to 2014. Computers in Human Behavior, 5, 349-358.

Phipps, R. A. (2015). Measuring quality in internet-based higher education. International Higher Education, 20, 2-3.

Pürbudak, A, Usta, E. (2019). Bellek destekli strateji yöntemiyle hazırlanmış dijital öykünün yabanc1 dil dersi tutumuna etkisi [The effect of digital storytelling with memory supported strategy method on attitude towards foreign language course]. Gazi Journal of Educational Sciences, 5 (2), 95-114. Retrieved from https://dergipark.org.tr/tr/pub/gebd/issue/47331/558216

Riding, R., \& Rayner, S. (1998a). Cognitive styles and learning strategies. London: David Fulton Publishers.

Riding, R., \& Rayner, S. (1998b). Cognitive Styles and learning strategies. London: David Fulton Publishers.

Schlosser, L. A., \& Simonson, M. (2006). Distance education: Definition and glossary of terms (2. b.). United States of America: IAP-Information Age Publishing, Inc.

Stacey, E. (2007). Collaborative learning in an online environment. International Journal of E-Learning \& Distance Education, 14(2), 14-33.

Triantafillou, E., Pomportsis, A., \& Demetriadis, S. (2003). The design and the formative evaluation of an adaptive educational system based on cognitive styles. Computers \& Education, 41(1), 87-103.

Tuan, H. L., Chin, C. C., \& Cheng, S. F. (2005). Investigating the effectiveness of inquiry instruction on the motivation of different learning styles student. International Journal of Science and Mathematics Education, 3(4), 541-566. https://doi.org/10.1007/s10763-004-6827-8

Uğur, B., Akkoyunlu, B., \& Kurbanoğlu, S. (2011). Students' opinions on blended learning and its implementation in terms of their learning styles. Education and Information Technologies, 16(1), 5-23. https://doi.org/10.1007/s10639-009-9109-9

Uygungül, Ö. (2016). Yaratıcı drama yönteminin ögrencilerin öğrenme stillerine göre Sosyal Bilgiler dersine yönelik tutumlarına, akademik başarılarına ve kalıcılı̆̆a etkisi [Effect of creative drama method on students' attitude towards social studies, academic achievement and retention by learning styles]. Çukurova University Institute of Social Sciences, Adana.

Veznedaroğlu, R. L., \& Özgür, A. O. (2005). Learning Styles: Definitions, models and functions. Elementary Online, 1-16.

Wang, Kua Hua, T. H. Wang, W. L. W. (2006). Learning styles and formative strategy: Enhancing student achievement in Web-based learning. Journal Of Computer Assisted Learning, 22(3), 207-217. 
Zhu, C. (2012). Student satisfaction, performance, and knowledge construction in online collaborative learning. S. Educational Technology \& Society, 15(1), 127-136. 